\title{
Determinants of the FDI Inflow into the Visegrad Countries ${ }^{1}$
}

\author{
Lubomír DARMO* -Marcel NOVÁK* - Marek KÁLOVEC** - \\ Petra RYBOŠOVÁ***
}

\begin{abstract}
The FDI inflow represents an important part of the Visegrad economies. These countries have experienced a high rate of foreign direct investment since the 1990s. However, the flow of investment is different among these countries with a diverse peak of inflow into individual economies. Slovakia, Czechia, Hungary and Poland reformed their political and economic systems and were considered as transition economies. Just like other transition economies, the economic, social and political system of the Visegrad Group countries have some peculiarities. The inflow of foreign direct investment is determined by many factors that might influence the inflow of foreign direct investment positively, but also in a negative way. The paper identifies specific determinants of the inflow of foreign direct investment into the Visegrad Group countries and it assess their impact on the investment inflow. We apply panel regression with the use of standardized variables. Based on the results, we may consider as determinants influencing the FDI inflow into the V4 countries the size of the economy, or its potential, labour productivity, corporate tax, wages, unit labour cost, inflation, education of workforce, openness of the economy, road and railway density, i.e., the quality or development of infrastructure, level of corruption in particular countries and membership of the Economic and Monetary Union.
\end{abstract}

Keywords: FDI inflow, GDP, labour productivity, openness of economy, Visegrad Group

JEL Classification: F21, O16, E24

DOI: https://doi.org/10.31577/ekoncas.2020.10.05

\footnotetext{
* Lubomír DARMO - Marcel NOVÁK, University of Economics in Bratislava, Faculty of National Economy, Department of Economics, Dolnozemská cesta 1, 85235 Bratislava 5, Slovakia; e-mail: lubomir.darmo@euba.sk; marcel.novak@euba.sk

** Marek KÁLOVEC, Ministry of Finance of the Slovak Republic, Institute for Financial Policy, Štefanovičova 5, 81782 Bratislava, Slovakia; e-mail: marek.kalovec@mfsr.sk

*** Petra RYBOŠOVÁ, The Financial Directorate of the Slovak Republic, Analysis and Prognosis Division Analysis of Financial policy Department, Lazovná 63, 97401 Banská Bystrica, Slovakia; e-mail: petra.rybosova@financnasprava.sk

${ }^{1}$ This paper was supported by the Grant Agency VEGA under its project No. 1/0356/19 Macroeconomic and Microeconomic Aspects of Indebtedness of Countries and Economic Subjects in the EU.
} 


\section{Introduction}

The Visegrad Group (V4 countries) is the common name for the group of four countries - Czechia, Hungary, Poland and Slovakia. These countries have very similar history, culture and three of them are Slavic nations. Moreover, until 1993, Czechia and Slovakia had formed one country. Similarly, Slovakia, Czechia and part of Poland belonged to Hungarian, or Austro-Hungarian Empire. Further on, the V4 countries were part of a block of socialist countries and transformed their economies after the collapse of the Soviet Union. All these factors have determined the development of the V4 economies.

The foreign direct investment (FDI) started to flow into the V4 countries immediately after the beginning of the transition process in early 1990s. Firstly, Hungary and Poland were the most attractive for foreign investors, Slovakia and Czechia started to arouse investors' interest at the end of 1990s. In spite of specific features of each country, they have some similarities and act as a homogenous group.

When analysing FDI determinants, the V4 countries have peculiarities that influence FDI inflow. These specific factors may influence the FDI inflow positively or in a negative way. Among positive determinants we identified a low labour costs, educated labour force, geographical location, privatization and consequent sale of privatized state-owned companies, accession to the European Union and adoption of single currency. Negative determinants are considered to be corruption, law enforcement, political stability, and infrastructure. The paper is organized as follows. The first part brings the literature review on the research of FDI determinants. The second part introduces the methodology of the paper. The third part analyses FDI determinants, identifies determinants specific for the V4 countries and assesses their role in influencing FDI inflow. The following part brings the policy implications and applications of results, and the last part draws conclusions.

\section{Literature Review}

Determinants of FDI inflow are represented by various features of a host country, which affect investors' decision to allocate investment in a particular country. These factors may be the size and character of market, access to new markets, production costs, regulation, investment incentives, and many others. Investors consider these factors in order to gain the highest possible profit, while FDI determinants are influencing the decision-making process of investment allocation as regards the selection of a host country and the volume, form and starting time of investment. 
Basically, we distinguish internal determinants that are related to the features of a company and its resources; and external factors - economic, social, cultural and legal determinants of environment in a country of origin and a host country of investment. Petříček (2003) divides determinants of FDI inflow into non-economic factors and economic factors.

Borrmann, Jungnickel and Keller (2015) classify FDI determinants in three groups. Firstly - market determinants such as GDP of a host country and GDP of its neighbour countries as potential markets, the level of development and population in the host country. The second group includes distance related factors. Usually, the distance between a host country and a country of investment origin is measured as the distance between their capital cities. This group also includes factors influencing trade relations - an openness ratio, common borders, common language, former colonialism, etc. The third group involves determinants relating to production factors, mainly to the labour force - labour productivity, education level, average and minimal wage and technological development of a host country.

Commonly, the FDI determinants are classified in three groups - political, economic and institutional (Bénassy-Quéré, Coupet and Mayer, 2007; Asiedu, 2006; Jadhav, 2012; Bouchoucha and Ammou, 2015; Busse and Hefeker, 2005; or Elkomy, Ingham and Read, 2015). The most noted theory related to the factors influencing investors' decision to invest abroad is the Dunning's OLI paradigm (Dunning, 2000) that defines three factors - ownership, location and internalization. A company will invest abroad if it obtains advantages from these factors when allocating its investment in a host country.

Starting with the empirical view on FDI determinants, many papers analysing FDI determinants apply the gravity model. The basic gravity model uses international trade of two countries as an endogenous variable. Exogenous variables are GNP of host and home countries, and the distance between them. The endogenous variable 'international trade' in this simplest model might be changed to a bilateral FDI flow between two countries. The model might be further extended to include other endogenous variables, such as population, common language, culture and history, colonial relations, neighbourhood of countries, common currency, integration area membership, trade agreements, etc. When analysing the main factor of the gravity model - distance, this might be represented by absolute distance, but also by relative distance. The relative distance captures various effects of international trade in relation to the distance between two countries and the rest of the world. It means that this pair of countries relatively outlying from other countries have more intensive bilateral trade than a pair of countries relatively closer to other countries (Kimura and Lee, 2006). 
Zarzoso and Lehmann (2003) use the population of home and host economies when analysing Mercosur - European Union trade flows. They incorporated these variable as the additional indicator of the size of the economy. They observe the negative effect of the size of home population on export. At the same time, the size of host country population has a positive effect on export. Moreover, the population positively affects FDI inflow into host country.

An important factor determining FDI inflow is a labour force with several indicators representing the labour force - number of workers, number of qualified labour, ratio of labour with third-level education to overall workforce, years of education, etc. Carr, Markusen and Maskus (2001) analysed the model of transnational corporation based on the human capital. They used variables of qualified workforce and non-qualified workforce combined with some other exogenous variables; and revenues of foreign affiliations in the period 1986 - 1994 as endogenous variable. They found that if the ratio of qualified workforce in a home country to the qualified workforce in a foreign country increases, the revenue, or FDI inflow from the home country into the host country, grows. This conclusion was disputed by Blonigen, Davies and Head (2003), as the former approach incorrectly defined differences between the qualified workforce of two countries. They tested a model by using a wider range of data and considered not only the data on FDI inflow for the USA but also for other OECD countries. They concluded that the flow of investment slowed with the increase in absolute value of difference in qualification between two countries.

The previous model based on the analysis of human capital was later extended by Bergstrand and Egger (2007) to include an additional FDI determinant - physical capital. They tested several assumptions as the mobility of physical capital, heterogeneous final product of foreign affiliations, production of goods by the use of three factors of production - qualified workforce, non-qualified workforce and physical capital. Results showed that an increasing volume of physical capital and an increasing number of qualified workforce in a home country are positively related to an increasing FDI flow from the home into the host country. These results confirm the result of Carr, Markusen and Maskus (2001). Authors also analysed a relation between trade agreements and FDI inflow. They confirmed the negative relation of these variables. Thus, the existence of trade agreements decreases an FDI flow between countries. After a trade agreement is applied, trade barriers are reduced and countries prefer international trade.

As we have mentioned, the cost of production, especially labour cost, is one of the most important FDI determinants. Bellak, Leibrecht and Riedl (2008) analysed FDI determinants in central and eastern Europe in the period 1995 - 2003 with the focus on labour cost. They expressed labour cost in two forms - the 
total cost that an investor pays for employing one employee and the gross wage of the employee. The difference between these forms was that total cost included also social contribution paid by the employer to a social and health insurance company. However, none of these forms included labour productivity. For that reason, the additional form - unit labour cost was analysed. The unit labour cost was expressed as the ratio of total cost of one employee to labour productivity. Authors observed negative relation between labour cost and FDI inflow into a host country. The growth of unit labour cost of $1 \%$ led to the decline of FDI inflow by $2.7 \%$.

Economic growth is also one of the determinant attracting foreign investors as the potential of economy raises. Hlavacek and Bal-Domanska (2016) analysed inflow of the foreign direct investment to Czech Republic, Estonia, Hungary, Latvia, Lithuania, Poland, Slovakia and Slovenia in period 2000 - 2012. They applied endogenous growth model and found that there is statistically significant relation between the economic growth and FDI.

Relating to the absorption capacity of the host countries, Kotíková (2019) quantified the local environment absorptive capacity and the technology gap between FDI and local businesses for the six Czech regions in 2018. The leading region has advantage of the geographical location and tradition of industrial companies. In addition, very important is high absorption capacity and potential for the economic growth found in the second best ranked region.

Similarly as in previous paper, Szent-Iványi and Vigvári (2012) deal with the potential of the countries to benefit from the FDI inflow. Authors analysed Czech Republic, Hungary, Poland and Slovakia focused on the manufacturing sector in period 2003 to 2007. Authors constructed an indicator measuring the potential by the use of six components, which are the main ways or channels how FDI affect the economy. Results showed that all countries were able to increase their potential to benefit from the FDI inflow during the analysed period. The highest potential was found for the Czech Republic and the least for the Poland.

To analyse the spillovers effects of the FDI inflow, the applied method of measurement might affect the result. Barrios, Görg and Strobl (2011) found that standard method of analysing backward spillovers effect with its restriction might fail to provide significance result. For that reason, alternative methods with restrained conditions would provide more robust results.

\section{Data and Methodology}

The literature review provides various determinants affecting FDI inflow into host countries. At the same time, it analyses the direction of impact of particular determinants on FDI inflow and considers whether these determinants are affecting 
FDI inflow positively or negatively. Based on this knowledge, we select determinants affecting FDI inflow into the V4 countries at the beginning of our analysis. We also make assumptions about the anticipated direction of the relation between FDI inflow into the V4 countries and individual determinants (whether the relation is to be positive or negative).

The goal of the paper is to identify and asses the determinants of FDI inflow into the V4 countries. We use the regression analysis to determine variables that relate to the FDI inflow into Czechia, Hungary, Poland and Slovakia for the period $2001-2014$, using the panel data. Therefore, we have 14-time periods and 4 cross-sections with the total of 56 observations. The data is gained from the databases of the UNCTADstat, the OECD, Eurostat and the World Bank Data. Source of the variables is given in Annex 6. Monetary variables are converted into the USD. They are adjusted for inflation and expressed in 2005 constant prices. The period starts in 2001 as we assume that since this period, mainly in Slovakia, FDI inflow increased rapidly as the result of the change of the government and taken measures in 1998. Measures related to the foreign policy including attitude to the foreign investors were focus on the attracting of the foreign investors and privatization processes. The analyzed period ends in 2014 . The reason of selection of this year is fact that analysis captures the same time period of the economic expansion before the global financial crisis has arisen (2001 - 2007) as well as the same time period of the financial crisis and subsequent recovery period $(2008-2014)$. This balance will secures the unbiased results and there is not prevalence of expansion period over the recovery period or vice versa that would affect the result of the analysis. Including the same 7 years period of expansion and recession/recovery period thus capture all phases of business cycle in $\mathrm{V} 4$ countries.

To estimate the relation between FDI inflow and its determinants, we used standardized variables. The standardization of variables means their transformation to such variables, whose mean is equal to zero and standard deviation is equal to one. The result of the estimation will not be the impact of particular variables or determinants on the FDI inflow into the V4 countries. However, the result will be how the unit change in the standard deviation of particular determinants affects the standard deviation in the FDI inflow. The standardization of variables has some proprieties. Is solves the issue of data non-stationarity. It is also efficient when data expressed in different units are used. The standardization transforms data to the same measure units and helps to interpret results.

We estimate four models in the first part of analysis - a relation between the FDI inflow and indicators measuring the size of economy (GDP, economic growth, potential product and production gap). While using standardized variables, 
the mean of the constant is equal to zero. For that reason, the constant for all V4 countries is the same (equal to zero).

In the following part, we select the indicators that measure the size of economy with the highest statistical significance and combine them with other variables selected as the potential determinants of FDI inflow into the V4 countries. Among these are also dummy variables that are not standardized. Therefore, the constant is not zero. For that reason, we have to focus on the testing statistic and select the most appropriate model. Exogenous variables were selected by the reverse step method. It means that we added all independent variables to the model and stepwise omit those that are not statistically significant or correlated to other variables and that might cause a bias in estimation results.

The closing part of the analysis assesses the estimated results and compare the relation between FDI inflow into the V4 countries and particular estimated FDI determinants with the assumed direction and influence.

\section{Results}

Based on literature review and theoretical background we identified factors influencing FDI inflow into the V4 countries (Annex 1).

All determinants showed in Annex 1 are used to estimate regression models of FDI inflow. Fundamental determinants are macroeconomic variables as GDP (GDP), economic growth (g), potential product (Yp) and production gap ( $\mathrm{Yr}-\mathrm{Yp}$ ). Other determinants of FDI inflow are factors influencing the macroeconomic situation and the level of development, such as the accessibility and education of labour force, labour cost and capital cost, tax burden and macroeconomic stability, development of infrastructure in a specific country, openness of the economy or international trade, and the labour and capital flow. Among these determinants there is missing a variable analysed in many theoretical and empirical papers, the basic determinant of gravity models - the distance between home and host countries. The paper does not consider this determinant because of the analysis of overall FDI inflow into the V4 countries in an aggregate form (no bilateral flows).

In addition to traditional determinants of FDI inflow, we also include less conventional variables such as number of internet users per 100 inhabitants (Internet). This variable, together with the road and railway density (Road_density, Railway_density) suggests the level of infrastructure development in the V4 countries and its impact on FDI inflow. We assume that the higher the number of internet users or the level of infrastructure, the higher the level of FDI inflow. The second unconventional variable is the employer's contributions to social 
insurance per employee (SSC). The contributions heighten the investment cost and may influence investors' decision to allocate FDI in the V4 countries (with a negative sign).

The last three determinants introduced in Annex 1 are dummy variables EU, EMU and Privat. These variables are specific for the transition countries trying to transform to market economies and integrate into the European Union. If a country became a member of the European Union (EU) in a particular year, the value of the dummy is 1 . Otherwise, it is 0 . The V4 countries entered the EU together in 2004. The dummy EU has taken the value 1 since that time. The same principle holds for the other dummies.

The variable EMU takes the value 1 if a country has adopted the common currency Euro. Otherwise, the value is 0. Slovakia adopted the Euro currency in 2009. Other V4 countries are not EMU members currently. The assumed impact of the EU and EMU membership on the FDI inflow is positive.

The third variable is privatization (Privat). The time period of the highest intensity of privatization obtains the value 1 . The termination of privatization or privatization at the low level takes the value 0 . To define the exact time of privatization' termination in particular countries is impossible. There are still stateowned companies that are planned to be privatized in the future. However, as the moment of termination we consider the period with the peak or maximum of privatized companies followed by a significant decline in this variable meaning a slow-down in the privatization process. The peak may be derived from the data on the number of the privatized companies with the asset value higher than USD 1 million during the period $2000-2008$. For the analysis purposes, as the privatization period we consider those years when the number of privatized companies is higher than the average (Annex 2). For these years the dummy Privat has the value 1 . For the years below the average the dummy equals zero. As in previous dummies, we assume that FDI inflow is higher in the time of privatization, i.e. the positive impact of privatization on FDI inflow.

Apart from the variable GDP and economic growth (g) in individual V4 countries, we have contemplated also the variable potential product $(\mathrm{Yp})$ and GDP gap ( $\mathrm{Yr}$ - Yp). In the first stage, FDI inflow may be formulated in a simplified way as a stepwise relation only to GDP, g, Yp, and Yr - Yp (Annex 3).

It should apply that the larger the economy, the higher the FDI inflow. For that reason, we assume a positive relation between GDP or economic growth and FDI inflow. This assumption is confirmed. Both have positive signs when analysing the FDI inflow into the V4 countries (Annex 3, Model 1 and Model 2). However, their significance levels are different. While GDP is significant at a $1 \%$ level, growth only at a $10 \%$ level. 
The potential product is the maximum output that might be produced by the economy with an exhaustive and effective use of sources. The higher the potential product, the higher the motivation of investors to allocate investment in these countries (Annex 3, Model 3). As in the previous estimations, the assumption is confirmed, and the significance level is $1 \%$.

The FDI inflow might be influenced also by the GDP gap. We assume a negative relation. The GDP gap balances the actual level of production against the potential product. If the real output is lower than potential, economy does not use all available sources and is under its productive capability. The unemployment is higher than the natural rate.

Therefore, there exists some space - unused potential for increasing the efficiency of production, the effective use of resources and achieving higher real GDP. Some space for new investment also exists in such a case. The relation of production gap to FDI inflow into the V4 countries is negative and that means: If the country is below its potential, its production gap is negative $(\mathrm{Yr}<\mathrm{Yp})$ and FDI inflow increases. On the contrary, if the gap is positive ( $\mathrm{Yr}>\mathrm{Yp}$ ), there are no additional resources that could be used, inflation increases, and the economy is in danger of overheating. It is obvious that FDI inflow will decline under these conditions. Even the analysis confirms the assumption on the positive relation between FDI inflow and production gap, variable is not statistically significant. For that reason, we have not use this variable in constructing the following estimations. We have neither use the variable economic growth. This determinant is significant, but only at a $10 \%$ significance level.

In the further step, we combine other determinants, primarily with GDP, and stepwise omit those that are not statistically significant. This reflects Model 1, when adding all other variables (Annex 4a, Model 1), that some of them are not significant or have not the assumed sign/direction (or both - e.g. interest rate (IR) or exchange rate volatility (RERvol)). GDP is statistically significant in the model but has the opposite sign than assumed. This may be caused by a high correlation with the variables labour force (LF), fixed capital (Capital) and unemployment (U). Moreover, these variables correlate with each other - labour force with capital; and labour force with unemployment. For that reason, we omit these variables from the analysis. If the estimation does not include these variables, the relation between GDP and FDI inflow is positive and significant at a $1 \%$ significance level (Annex 4a, Model 2).

Due to the correlation with other variables, there might also be a problem with the variables social contributions (SSC) and Internet. The Internet claims a positive relation with FDI inflow, as we have assumed. However, it is statistically not significant and highly correlated with the variables Inflation and EU. 
For that reason, we omit the variable from the estimation. We also omit the SSC variable, although this determinant is significant, with the assumed sign/direction. However, it correlates with the variable Railway_density. We keep the variable Railway_density. This determinant of FDI inflow is supported by literature and has also higher significance than the SSC variable in Model 2. We get Model 3 (Annex 4a) after omitting the variables Internet and SSC.

After omitting variables with a high mutual correlation, we consecutively omit variables that have no or only little significance. Such variable is the exchange rate volatility (RERvol) in Model 3. The exchange rates of the V4 countries are relatively stable, with minimum fluctuations, and do not influence the decisions of investors. For example, Slovakia was part of the ERM II from 2005, i.e., four years before the adoption of the common currency. At that time, the Slovak koruna could not devaluate, exceed its fluctuation band, and must have moved around its central parity. The variable RERvol is therefore omitted from the estimation (Annex 4a, Model 4). In this formula, the variable EU has the highest p-value (the lowest statistical significance).

The V4 countries have been EU members since 2004. In spite of unarguable/undeniable advantages of the EU membership, in particular the free movement of goods, services and capital, the membership has no important impact on the FDI inflow into the V4 countries. Investors have tried to take advantage of investing in these countries without regard to their membership of the EU, considering other factors such as cheap labour, labour productivity, profitability of investment, and the potential of a country to grow in the future. Owing to this, we also omit the variable EU from the estimation (Annex 4b, Model 5). The last two statistically insignificant variables in the analysis are the factors of privatization (Privat) and interest rate (IR).

The variable Privat has smaller significance, therefore we omit it first (Annex 4b, Model 6), followed by the variable IR (Annex 4b, Model 7). Despite the assumption or high probability that privatization would lead to a heightened FDI inflow into the V4 countries, according to the results of Model 1 privatization and FDI inflow go in an opposite way (the negative sign). Moreover, this variable is not significant. Such result is influenced by the measure of the variable Privat. We know that the privatization process was applied also to companies with an asset value lower than USD 1 million. Unfortunately, this data is not available. The result may also be influenced by the method of privatization, mainly in the first phase of privatization - the sale of companies exclusively to domestic investors/entrepreneurs for prices below the market value of the privatized companies, while the sale often disrupted market principles. Corruption was also unexceptional. 
The variable interest rate (IR) is also statistically insignificant. Investment, or the capital flowing into the V4 countries, comes from home countries and financial markets. Therefore, the price of capital in host countries does not have any important role in the decision making process of investors. The constant in the estimation is neither significant and is omitted (Annex 4b, Model 8).

After omitting variables that are not statistically significant, the determinants influencing the FDI inflow into the V4 countries are considered to be GDP, Prod, TAXrate, Wages, ULC, Infl, Skill, Openness, Road_density, Railway_density, Corrup, and EMU (all the variables are statistically significant at the level of significance $\alpha=1 \%$, with the exception of EMU and Infl with significance $\alpha=5 \%$ ).

Similarly, we analyse the relation between FDI inflow and certain FDI determinants, using the variable potential product the analysis method is the same and the results of such modified model are almost the same as in the previous specification. Firstly, we include all variables to the right side of the estimation as exogenous variables (of course, without FDI inflow that is endogenous). Consequently, we omit variables with a high mutual correlation - Capital, LF, U, SSC, and Internet (Annex 5a, Model 1, 2 and 3). Further, variables with a high p-value are omitted stepwise. The following estimation does not include the variable Privat (Annex 5a, Model 4). The relation of this variable to the FDI inflow into the V4 countries is positive but statistically insignificant. Insignificant is also the variable EMU, and is therefore omitted (Annex 5a, Model 5). The same applies to the variables RERvol and IR. After omitting these variables, insignificant become the determinants EU and Corrup and the constant. We gradually omit them from the estimation (Annex 5b, Models $6-10$ ). With the use of the potential product as the measure of the economy size, the significant variables, i.e., the determinants of the FDI inflow into the V4 countries, are Prod, TAXrate, Wages, ULC, Infl, Skill, Openness, Road_density, and Railway_density (all the variables are statistically significant at the level of significance $\alpha=1 \%$ ).

The estimation with the potential product (adjusted $\mathrm{R}^{2}=57.5 \%$ ) brings a higher variability of the dependent variable explained by exogenous variables. However, the coefficient of determination in the first estimation is smaller only by few percentage points. Furthermore, in both estimations, almost the same determinants are statistically significant. Only the variables Corrup and EMU differ. These seem to be significant only in the estimation, which uses the variable GDP. We estimate both specified models of the FDI inflow into the V4 countries applying the standardized values of variables. This method allows us to determine those variables/determinants that may have the highest impact on the FDI inflow. The most significant determinants that motivate investors to allocate investments to the V4 countries are the size and development of the economy, 
quality of skilled labour force, development of infrastructure (specifically the road network) and openness of the economy. All these factors have a positive relation to the FDI inflow into the V4 countries.

\section{Policy Implications}

Based on the results of the regression analysis, we may consider as determinants influencing the FDI inflow into the V4 countries the size of the economy, or its potential, labour productivity, corporate tax, wages, unit labour cost, inflation, education of workforce, openness of the economy, road and railway density, i.e., the quality or development of infrastructure, level of corruption in particular countries and membership of the Economic and Monetary Union. The following table refers to the overview of analysed potential determinants of FDI inflow. It demonstrates, which determinants are statistically significant and which are not. We may also see the comparison of the assumed and estimated direction (sign) of certain determinants (positive relation + , negative relation - ) to FDI inflow.

T a ble 1

The Comparison of the Assumed and Estimated Relation between FDI Determinants and FDI Inflow

\begin{tabular}{|l|c|c|c|}
\hline & Assumed relation & Statistical significance & Estimated relation \\
\hline s_GDP & + & Yes & + \\
s_Yp & + & Yes & + \\
s_Prod & + & Yes & + \\
s_TAXrate & - & Yes & - \\
s_Capital & + & Yes & - \\
s_Wages & - & Yes & + \\
s_ULC & - & Yes & - \\
s_Infl & - & & + \\
s_LF & + & Yes & \\
s_U & + & & + \\
s_Skill & + & & + \\
s_IR & - & & + \\
s_SSC & - & Yes & + \\
s_RERvol & - & Yes & + \\
s_Openness & + & Yes & \\
s_Road_density & + & & - \\
s_Railway_density & + & Yes & \\
s_Internet & + & & \\
s_Corrup & - & Yes & \\
EU & + & & \\
EMU & + & & \\
Privat & + & &
\end{tabular}

Source: Authors.

From the statistically significant determinants of the FDI inflow into the V4 countries, only the unit labour cost and the membership of the Euro Area are 
opposite to the assumed direction. Except for gross wage the unit labour cost also includes other components - social contributions, employee benefits, continuous training of employees, provision and cost of working clothes, recruitment cost, etc. Some of the costs are recognized as tax expenses that lower a tax base and thus the income tax. A specific example is the expense on research and development (R\&D). This additional tax deduction allows investors to deduct expenses on R\&D from their tax base, which should positively influence their investment decisions. The objective of this measure is to support investment in R\&D. For example, Slovakia provides the so called "super deduction of expenses on R\&D" to legal entities. From their tax base, entities engaged in R\&D may deduct $25 \%$ of their expenses on R\&D, $25 \%$ of wage costs of employees working on $R \& D$ projects, and $25 \%$ of the amount by which present expenses on $R \& D$ exceed the previous year's R\&D expenses (PwC, 2016).

We also assume the positive relation of FDI inflow and the membership in the Euro Area. However, such assumption is not confirmed by the result of our estimation. This variable relates only to one of the V4 countries - Slovakia. The Euro can be adopted after fulfilling the convergence criteria. The members of the Euro Area must assign for price and financial stability. This can be a positive signal for potential investors.

The analysis confirms several theoretical assumptions. It is true that a larger size of the economy means a higher FDI inflow. Labour productivity represents the level of production confined to one unit of labour (one employee). The higher is productivity, the more effective and profitable becomes production. Therefore investors have greater motivation and incentive to realize investment in a particular country. Our estimation confirms also this assumption. The variable TAXrate refers to the corporate income tax and represents the level of taxation in individual V4 countries. As we have assumed and the analysis confirms it, higher taxation refers to a lower FDI inflow due to higher costs for investors. Presently, corporate tax in Czechia and Poland is 19\%. In Hungary it was 19\% until 2016 and has lowered to 9\% since the 2017. Although the tax rate declined in Slovakia in 2017, from 22\% to $21 \%$, it has remained the highest among the V4 countries (OECD, 2017). The decrease in the tax rate in Slovakia and Hungary may have positive effect on investors' decisions and increase the level of FDI inflow into these countries.

The variable Wages presents a cost for investors and therefore negatively affects FDI inflow. Inflation also affects FDI inflow negatively, as we have assumed. The real interest rate is considered as the rate of return. It is calculated as a difference between the nominal interest rate and the inflation rate. The higher the inflation, the lower the real interest rate, thus the potential yield of investment. As a result, a negative relation between inflation and FDI inflow is observed. 
Another important FDI determinant is the level of labour education or availability of a skilled workforce. This determinant is expressed by the variable Skill that refers to the ratio of persons in the age of $25-64$ with completed secondary education to total population. Most of FDI flowing into the V4 countries is oriented to manufacturing. Anyway, manufacturing sectors also need the workforce with a certain level of education and skills - workers able to operate and run machines and facilities. This assumption is confirmed and the variable Skill relates to FDI inflow positively. The openness of economy is the ratio of import and export to GDP and has a positive impact on FDI inflow into the V4 countries. The V4 countries are considered as very open economies - especially Slovakia. The higher the openness, the easier the export of production or import of new technologies or other inputs necessary for the production of goods and services.

Similar to the openness, a positive relation between FDI inflow and infrastructure (Road_density and Railway_density) is also estimated. A higher density of roads and railways is associated with more intensive FDI inflow into the V4 countries. The density of transport infrastructure is relatively high in the V4 countries. However, the share of motorways is low. For that reason, the countries have to focus on the construction of higher class roads such as main highways and expressways, as well as on the maintenance of the existing transport network. Generally, poor infrastructure impedes the development of an economy.

Corruption relates to FDI inflow negatively and is statistically significant. Corruption is often a consequence of intricate processes, bureaucracy and time necessary to arrange various administrative requirements. Corruption distorts the principles of competitiveness and market economy. It increases costs for investors, but mainly heightens the risk of non-law enforcement. Corruption is present in economic systems of all V4 countries. The origin of corruption has historical context and comes from the period of centrally planned economy, which had been applied in the V4 countries until 1989. In order to gain more effective economy, better resources allocation, better use of potential of the V4 countries, and in order to increase FDI inflow into these countries, it is necessary that corruption be eliminated from their governance systems (better transparency, obligation to provide information, electronic systems for public administration, etc.).

\section{Conclusion}

The goal of the paper is to identify and asses the determinants of FDI inflow into the V4 countries. We have found that the crucial factor of FDI inflow is size of these economies, or their economic potential. GDP is a signal of growing prosperity and new investment possibilities. As the results show, other important 
determinants of FDI inflow are labour productivity, workforce education, economy openness and infrastructure. These factors stimulate FDI inflow. On the other hand, determinants negatively influencing FDI inflow are corporate taxes and wages, which represent costs of production. Similarly, inflation also exerts a negative effect on FDI inflow. Since inflation has been very low in recent years, its impact was more important at the beginning of the study period. A considerable issue and determinant negatively influencing FDI inflow is corruption. Venal environment increases suspicion and doubts of investors, raises transactional costs and hampers FDI inflow into a host country. The assessed effect of examined determinants of FDI inflow is the same as the results of other papers, e.g. Kimura and Lee (2006) - a positive effect of GDP; Carr, Markusen and Maskus (2001) a positive effect of qualified labour force; Bénassy-Quéré, Fontagné and Lahrèche-Révil (2005) - a negative effect of taxes; Demirhan and Masca (2008), Asiedu (2006); Ancharaz (2003) - a positive effect of openness on FDI inflow; Xaypanya, Rangkakulnuwat and Paweenawat (2015), Asiedu (2006) - a negative effect of inflation; Obwona (2001), Makabenta (2002), Li and Park (2006) - a positive effect of infrastructure; Wei (2000), Habib and Zurawicki (2002), Hajzler and Rosborough (2016) - a negative effect of corruption.

Among the above-mentioned determinants of FDI inflow, the most important effect on the FDI inflow is attached to the size and development of economy, the level of qualified labour force, development of infrastructure and openness of economy. The FDI inflow may generate several positive effects on a host economy - job creation, increased competitiveness, technological spillover effects, and economic growth. For this reason, the V4 countries should focus on improving and supporting those determinants that have the highest impact on the FDI inflow. The countries should support investment in human capital, ensure that inhabitants have access to high-quality education, support programs of education for older people, and maintain or increase the level of education of their labour force. The countries should also support international trade and create or keep good relations with their trade partners.

The V4 countries are open economies, therefore the reduction of any restrictions to international trade would lead to transactional cost cuts and FDI inflow increases. Finally, probably the most important investment that heightens FDI inflow is investment in infrastructure. Countries need to improve and modernize existing road and railway networks, build new speedways and railways, to increase the density of infrastructure necessary for the transport of produced goods. This measure would attract higher investment, particularly to the V4 regions which have several advantages for running business but are limited by transportation infrastructure. This is one of the ways of how the V4 countries might create more favourable business environment, increase regional GDP and development of their regions. 
The main contribution of the paper is the identification of specific determinants of the FDI inflow to V4 countries. We have found that the FDI inflow is determined by many variables commonly assumed to attract FDI. However, we have found that some determinants are not statistically significant even we assumed they might play an important role in attracting FDI in the V4 countries. These variables are labour force, unemployment, social security contributions, membership in the European Union or privatization.

The paper deals with the identification of the FDI determinants in the V4 countries. Following this paper, we would like to progress with the analysis and focus on the peculiarities of the FDI determinants in the V4 countries as well as on the particularised analysis of the each V4 country.

\section{References}

ANCHARAZ, V. D. (2003): The Determinants of Foreign Direct Investment in a Comparative Perspective: Is there a Bias against Sub-Saharan Africa? [Online.] Moka: University of Mauritius. Available at: 〈http://www.uvm.edu/ wgibson/PDF/FDIinSSA.pdf >. Accessed 10 February 2017.

ASIEDU, E. (2006): Foreign Direct Investment in Africa: The Role of Natural Resources, Market Size, Government Policy, Institutions and Political Instability. The World Economy, 29, No. 1, pp. $63-77$.

BARRIOS, S - GÖRG, H. - STROBL, E. (2011): Spillovers through Backward Linkages from Multinationals: Measurement Matters! European Economic Review, 55, No. 6, pp. 862 - 875.

BELLAK, CH. - LEIBRECHT, M. - REIDL, A. (2008): Labour Costs and FDI Flows into Central and Eastern European Countries: A Survey of the Literature and Empirical Evidence. Structural Change and Economic Dynamics, 19, No. 1, pp. 17 - 37.

BÉNASSY-QUÉRÉ, A. - COUPET, M. - MAYER, T. (2007): Institutional Determinants of Foreign Direct Investment. The World Economy, 30, No. 5, pp. $764-782$.

BÉNASSY-QUÉRÉ, A. - FONTAGNÉ, L. - LAHRÈCHE-RÉVIL, A. (2005): How does FDI React to Corporate Taxation? International Tax and Public Finance, 12, No. 5, pp. $583-603$.

BERGSTRAND, J. H. - EGGER, P. (2007): A Knowledge-and-Physical-Capital Model of International Trade Flows, Foreign Direct Investment, and Multinational Enterprises. Journal of International Economics, 73, No. 3, pp. $278-308$.

BLONIGEN, B. A. - DAVIES, R. B. - HEAD, K. (2003): Estimating the Knowledge-Capital Model of the Multinational Enterprise: Comment. The American Economic Review, 93, No. 3, pp. 980 - 994.

BORRMANN, CH. - JUNGNICKEL, R. - KELLER, D. (2015): What Gravity Models can Tell Us about the Position of German FDI in Central and Eastern Europe. Hamburg: Hamburg Institute of International Economics. Available at: <http://ageconsearch.tind.io//bitstream/26386/1/dp050328.pdf >. Accessed 20 September 2018.

BOUCHOUCHA, N. - AMMOU, S. B. (2015): Political and Institutional Determinants of Foreign Direct Investment: An Application for MENA Region Countries. International Journal of Science and Research, 4, No. 8, pp. $1866-1871$.

BUSSE, M. - HEFEKER, C. (2005): Political Risk, Institutions and Foreign Direct Investment. Hamburg: Hamburg Institute of International Economics. Available at: <https://www.econstor.eu/bitstream/10419/19287/1/315.pdf>. Accessed 2 August 2018. 
CARR, D. L. - MARKUSEN, J. R. - MASKUS, K. E. (2001): Estimating the Knowledge-capital Model of the Multinational Enterprise. American Economic Review, 91, No. 3, pp. $693-708$.

DEMIRHAN, E. - MASCA, M. (2008): Determinants of Foreign Direct Investment Flows to Developing Countries: A Cross-Sectional Analysis. Praha: University of Economics, Prague Economic Papers. Available at: <https://www.vse.cz/pep/337?lang=en>. Accessed 10 February 2017.

DUNNING, J. H. (2000): The Eclectic Paradigm as an Envelope for Economic and Business Theories of MNE Activity. International Business Review, 9, No. 2, pp. 163 - 190.

ELKOMY, S. - INGHAM, H. - READ, R. (2015): Economic, Institutional \& Political Determinants of FDI Growth Effects in Emerging \& Developing Countries. Lancaster: Lancaster University. Available at: <http://www.lancaster.ac.uk/media/lancaster-university/content-assets/documents/ lums/economics/working-papers/LancasterWP2015_024.pdf>. Accessed 2 February 2018.

HABIB, M. - ZURAWICKI, L. (2002): Corruption and Foreign Direct Investment. Journal of International Business Studies, 33, No. 2, pp. $291-307$.

HAJZLER, CH. - ROSBOROUGH, J. (2016): Government Corruption and Foreign Direct Investment under the Threat of Expropriation. Ottawa: Bank of Canada. Available at: <http://www.bankofcanada.ca/wp-content/uploads/2016/03/swp2016-13.pdf >. Accessed 10 February 2017.

HLAVACEK, P. - BAL-DOMANSKA, B. (2016): Impact of Foreign Direct Investment on Economic Growth in Central and Eastern European Countries. Engineering Economics, 27, No. 3, pp. $294-303$.

JADHAV, P. (2012): Determinants of Foreign Direct Investment in BRICS Economies: Analysis of Economic, Institutional and Political Factor. Procedia - Social and Behavioral Sciences, 37, pp. $5-14$.

KIMURA, F. - LEE, H. H. (2006): The Gravity Equation in International Trade in Services. Review of World Economics, 142, No. 1, pp. $92-121$.

KOTÍKOVÁ, S. (2019): Potential of the Czech Business Environment Assumes the Effects of Foreign Direct Investment. E+M Ekonomie a Management, 22, No. 4, pp. 18 - 35.

LI, S. - PARK, S. H. (2006): Determinants of Locations of Foreign Direct Investment in China. Management and Organization Review, 2, No. 1, pp. 95 - 119.

MAKABENTA, M. P. (2002): FDI Location and Special Economic Zones in the Philippines. Review of Urban and Regional Development Studies, 14, No. 1, pp. $59-77$.

OBWONA, M. B. (2001): Determinants of FDI and their Impact on Economic Growth in Uganda. African Development Review, 13, No. 1, pp. $46-81$.

OECD (2017): Corporate Income Tax Rate. Paris: OECD. Available at: <http://stats.oecd.org/Index.aspx?DataSetCode=TABLE_II1>. Accessed 20 September 2018.

PETŘíČEK, V. (2003): Vývoj investičního prostředí v České republice. Praha: Corona, 108 p.

PwC (2016): Dane do vrecka 2016. Available at: <https://www.pwc.com/sk/sk/publikacie/assets/2016/dane-do-vrecka-2016.pdf>. Accessed 20 September 2017.

SZENT-IVÁNYI, B. - VIGVÁRI. G. (2012): Spillovers from Foreign Direct Investment in Central and Eastern Europe. Society and Economy, 34, No. 1, pp. $51-72$.

WEI, S. J. (2000): How Taxing Is Corruption on International Investors? Review of Economics and Statistics, 82, No. 1, pp. $1-11$.

XAYPANYA, P. - RANGKAKULNUWAT, P. - PAWEENAWAT, S. W. (2015): The Determinants of Foreign Direct Investment in ASEAN. The First Differencing Panel Data Analysis. International Journal of Social Economics, 42, No. 3, pp. $239-250$.

ZARZOSO, I. M. - LEHMANN, F. N. (2003): Augmented Gravity Model: An Empirical Application to Mercosur-European Union Trade Flows. Journal of Applied Economics, 6, No. 2, pp. $291-316$. 
An nexes

A n n e x 1

Potential Determinants of FDI Inflows into the V4 Countries - Sorts, Labels and Assumed Impact

\begin{tabular}{|c|c|c|c|}
\hline & Determinants of FDI inflow into V4 countries & Abbreviation (label) & $\begin{array}{c}\text { Assumed } \\
\text { impact }\end{array}$ \\
\hline $\begin{array}{l}\text { Fundamental } \\
\text { determinants } \\
\text { of FDI inflow }\end{array}$ & $\begin{array}{l}\text { Size of the economy } \\
\text { Economic growth } \\
\text { Potential product } \\
\text { GDP gap (production gap) }\end{array}$ & $\begin{array}{l}\text { s_GDP } \\
\text { s_g } \\
\text { s_Yp } \\
\text { s_(Yr - Yp) }\end{array}$ & $\begin{array}{l}+ \\
+ \\
+ \\
-\end{array}$ \\
\hline $\begin{array}{l}\text { Other } \\
\text { determinants } \\
\text { of FDI inflow }\end{array}$ & $\begin{array}{l}\text { Labour productivity } \\
\text { Taxes (corporate) } \\
\text { Fixed capital } \\
\text { Wage } \\
\text { Unit labour cost } \\
\text { Inflation (CPI index) } \\
\text { Labour force } \\
\text { Unemployment } \\
\text { Skilled labour force } \\
\text { Long-term interest rate } \\
\text { Social insurance contributions } \\
\text { Exchange rate volatility } \\
\text { Openness of the economy } \\
\text { Road density } \\
\text { Railway density } \\
\text { Internet } \\
\text { Corruption } \\
\text { EU membership } \\
\text { Euro area membership } \\
\text { Privatization }\end{array}$ & $\begin{array}{l}\text { s_Prod } \\
\text { s_TAXrate } \\
\text { s_Capital } \\
\text { s_Wages } \\
\text { s_ULC } \\
\text { s_Infl } \\
\text { s_LF } \\
\text { s_U } \\
\text { s_Skill } \\
\text { s_IR } \\
\text { s_SSC } \\
\text { s_RERvol } \\
\text { s_Openness } \\
\text { s_Road_density } \\
\text { s_Railway_density } \\
\text { s_Internet } \\
\text { s_Corrup } \\
\text { EU } \\
\text { EMU } \\
\text { Privat }\end{array}$ & $\begin{array}{l}+ \\
- \\
+ \\
- \\
- \\
- \\
+ \\
+ \\
+ \\
- \\
- \\
- \\
+ \\
+ \\
+ \\
+ \\
- \\
+ \\
+ \\
+\end{array}$ \\
\hline
\end{tabular}

Note: "s" in Abbreviation (label) column = standardized variable.

Source: Authors. 
Annex 2

The Number of Privatized Companies with the Asset Value Exceeding USD 1 Mil. in the Period 2000 - 2008

\begin{tabular}{|l|r|r|r|r|r|r|r|r|r|r|}
\hline & $\mathbf{2 0 0 0}$ & $\mathbf{2 0 0 1}$ & $\mathbf{2 0 0 2}$ & $\mathbf{2 0 0 3}$ & $\mathbf{2 0 0 4}$ & $\mathbf{2 0 0 5}$ & $\mathbf{2 0 0 6}$ & $\mathbf{2 0 0 7}$ & $\mathbf{2 0 0 8}$ & Average \\
\hline Czechia & 9 & 13 & 7 & 6 & 4 & 4 & 0 & 3 & 1 & 5,2 \\
Hungary & 6 & 5 & 1 & 6 & 11 & 5 & 3 & 2 & 0 & 4,3 \\
Poland & 18 & 15 & 16 & 12 & 5 & 10 & 7 & 5 & 7 & 10,6 \\
Slovakia & 5 & 6 & 10 & 3 & 3 & 3 & 2 & 1 & 0 & 3,7 \\
\hline
\end{tabular}

Source: World Bank.

A n n e x 3

The Relation between Fundamental Determinants and FDI Inflow into the V4 Countries

\begin{tabular}{|l|c|c|c|c|}
\hline & Model 1 & Model 2 & Model 3 & Model 4 \\
\hline s_GDP & $\begin{array}{c}0.559^{* * *} \\
\text { s_g }\end{array}$ & & & \\
s_Yp & & $0.305 *$ & \\
s_Yr-Yp & & $(0.063)$ & $0.582^{* * *}$ & \\
R & & & $(1.67 \mathrm{e}-012)$ & -0.013 \\
\hline Appropriate model & Pooled OLS & Pooled OLS & Pooled OLS & $(0.754)$ \\
\hline
\end{tabular}

Note: $* * *=1 \%$ significance level, $* *=5 \%$ significance level, $*=10 \%$ significance level.

Source: Authors' estimation. 
A n n e x 4a

The Relation of GDP and Other Determinants with the FDI Inflow into the V4 Countries

\begin{tabular}{|c|c|c|c|c|}
\hline & Model 1 & Model 2 & Model 3 & Model 4 \\
\hline \multirow[t]{2}{*}{ s_const } & -0.258 & -0.418 & -0.381 & -0.382 \\
\hline & $(0.6082)$ & $(0.4393)$ & $(0.4803)$ & $(0.4928)$ \\
\hline \multirow{2}{*}{ s_GDP } & $-2.811^{* * *}$ & $1.745^{* * *}$ & $1.971 * * *$ & $1.970 * * *$ \\
\hline & $(8.49 \mathrm{e} 05)$ & $(0.0044)$ & $(0.0001)$ & $(0.0002)$ \\
\hline \multirow[t]{2}{*}{ s_Prod } & $0.624 * * *$ & $0.557 * * *$ & $0.447 * * *$ & $0.447 * * *$ \\
\hline & $(0.0002)$ & $(0.0004)$ & $(1.65 \mathrm{e}-06)$ & $(6.58 \mathrm{e}-07)$ \\
\hline \multirow[t]{2}{*}{ s_TAXrate } & $-0.327^{*}$ & $-0.362 * *$ & $-0.412^{* *}$ & $-0.413 * * *$ \\
\hline & $(0.0911)$ & $(0.0461)$ & $(0.0140)$ & $(0.0099)$ \\
\hline \multirow[t]{2}{*}{ s_Capital } & $3.125 * * *$ & & & \\
\hline & $(1.32 \mathrm{e}-05)$ & & & \\
\hline \multirow[t]{2}{*}{ s_Wages } & -0.249 & -0.238 & $-0.455^{* * *}$ & $-0.455^{* * *}$ \\
\hline & $(0.2138)$ & $(0.1712)$ & $(0.0006)$ & $(0.0005)$ \\
\hline \multirow[t]{2}{*}{ s_ULC } & 0.135 & $0.226^{* *}$ & $0.188^{* *}$ & $0.187 * *$ \\
\hline & $(0.4479)$ & $(0.0417)$ & $(0.0405)$ & $(0.0351)$ \\
\hline \multirow[t]{2}{*}{ s_Infl } & -0.303 & -0.849 & $-0.487 * *$ & $-0.486^{* *}$ \\
\hline & $(0.5050)$ & $(0.1317)$ & $(0.0370)$ & $(0.0461)$ \\
\hline \multirow[t]{2}{*}{ s_LF } & 0.514 & & & \\
\hline & $(0.6238)$ & & & \\
\hline \multirow[t]{2}{*}{ s_U } & 0.476 & & & \\
\hline & $(0.1575)$ & & & \\
\hline \multirow[t]{2}{*}{ s_Skill } & $0.739 * *$ & $1.137 * *$ & $1.216^{* * *}$ & $1.215^{* * *}$ \\
\hline & $(0.0250)$ & $(0.0294)$ & $(0.0009)$ & $(0.0011)$ \\
\hline \multirow[t]{2}{*}{ s_IR } & 0.014 & 0.213 & 0.208 & 0.208 \\
\hline & $(0.9535)$ & $(0.3309)$ & $(0.1586)$ & $(0.1712)$ \\
\hline \multirow[t]{2}{*}{ s_SSC } & -0.120 & $-0.532 *$ & & \\
\hline & $(0.4036)$ & $(0.0897)$ & & \\
\hline \multirow[t]{2}{*}{ s_RERvol } & 0.101 & -0.037 & 0.001 & \\
\hline & $(0.4432)$ & $(0.6582)$ & $(0.9774)$ & \\
\hline \multirow[t]{2}{*}{ s_Openness } & $0.321^{* *} *$ & $0.978 * *$ & $1.009^{* *}$ & $1.008 * *$ \\
\hline & $(0.0375)$ & $(0.0391)$ & $(0.0177)$ & $(0.0191)$ \\
\hline \multirow[t]{2}{*}{ s_Road_density } & $0.982 * * *$ & $1.228 * * *$ & $1.130 * * *$ & $1.129 * * *$ \\
\hline & $(0.0034)$ & $(0.0067)$ & $(0.0067)$ & $(0.0095)$ \\
\hline \multirow[t]{2}{*}{ s_Railway_density } & 0.004 & $0.722 * *$ & $0.365^{*}$ & $0.365^{*}$ \\
\hline & $(0.9908)$ & $(0.0414)$ & $(0.0546)$ & $(0.0581)$ \\
\hline \multirow[t]{2}{*}{ s_Internet } & 0.160 & 0.181 & & \\
\hline & $(0.8201)$ & $(0.8019)$ & & \\
\hline \multirow[t]{2}{*}{ s_Corrup } & -0.194 & $-0.351 * * *$ & $-0.406^{* * *}$ & $-0.405^{* * *}$ \\
\hline & $(0.1350)$ & $(1.17 e-06)$ & $(5.51 \mathrm{e} 07)$ & $(1.67 \mathrm{e} 06)$ \\
\hline \multirow[t]{2}{*}{ EU } & 0.400 & 0.545 & 0.468 & 0.469 \\
\hline & $(0.4987)$ & $(0.4140)$ & $(0.4721)$ & $(0.4850)$ \\
\hline \multirow[t]{2}{*}{ EMU } & $-0.342^{*}$ & -0.289 & -0.387 & -0.387 \\
\hline & $(0.0823)$ & $(0.2714)$ & $(0.1917)$ & $(0.1651)$ \\
\hline \multirow[t]{2}{*}{ Privat } & -0.085 & 0.089 & 0.236 & 0.236 \\
\hline & $(0.7497)$ & $(0.6995)$ & $(0.4176)$ & $(0.4020)$ \\
\hline Adjusted R ${ }^{2}$ & 0.5762 & 0.5031 & 0.5176 & 0.5297 \\
\hline Appropriate model & Pooled OLS & Pooled OLS & Pooled OLS & Pooled OLS \\
\hline
\end{tabular}

Note: $* * *=1 \%$ significance level, $* *=5 \%$ significance level, $*=10 \%$ significance level.

Source: Authors' estimation. 
A n nex 4 b

The Relation of GDP and Other Determinants with the FDI Inflow into the V4 Countries

\begin{tabular}{|c|c|c|c|c|}
\hline & Model 5 & Model 6 & Model 7 & Model 8 \\
\hline \multirow[t]{2}{*}{ s_const } & 0.001 & $0.030^{*}$ & 0.0366 & \\
\hline & $(0.9419)$ & $(0.0673)$ & $(0.1723)$ & \\
\hline \multirow[t]{2}{*}{ s_GDP } & $2.144 * * *$ & $2.083^{* * *} *$ & $1.936 * * *$ & $1.956 * * *$ \\
\hline & $(5.06 \mathrm{e}-09)$ & $(3.80 \mathrm{e}-08)$ & $(5.91 e-08)$ & $(3.40 \mathrm{e}-08)$ \\
\hline \multirow[t]{2}{*}{ s_Prod } & $0.431 * * *$ & $0.438 * * *$ & $0.437 * * *$ & $0.447 * * *$ \\
\hline & $(6.89 \mathrm{e}-08)$ & $(5.18 \mathrm{e}-08)$ & $(3.94 \mathrm{e}-08)$ & $(1.70 \mathrm{e}-08)$ \\
\hline \multirow[t]{2}{*}{ s_TAXrate } & $-0.526^{* * *}$ & $-0.506^{* * *}$ & $-0.467 * * *$ & $-0.476^{* * *}$ \\
\hline & $(6.63 e-08)$ & $(1.07 \mathrm{e}-08)$ & $(3.67 \mathrm{e}-013)$ & $(1.64 \mathrm{e}-013)$ \\
\hline \multicolumn{5}{|l|}{ s_Capital } \\
\hline \multirow[t]{2}{*}{ s_Wages } & $-0.503 * * *$ & $-0.493 * * *$ & $-0.446^{* * *}$ & $-0.443^{* * *}$ \\
\hline & $(4.24 \mathrm{e}-05)$ & $(4.05 e-06)$ & $(3.26 \mathrm{e}-012)$ & $(1.07 \mathrm{e}-013)$ \\
\hline \multirow[t]{2}{*}{ s_ULC } & $0.154 * * *$ & $0.154 * * *$ & $0.203 * * *$ & $0.206^{* * *}$ \\
\hline & $(0.0038)$ & $(0.0036)$ & $(3.20 \mathrm{e}-018)$ & $(1.03 e-016)$ \\
\hline \multirow[t]{2}{*}{ s_Infl } & $-0.522 * *$ & $-0.528 * *$ & $-0.531 * *$ & $-0.549 * *$ \\
\hline & $(0.0148)$ & $(0.0103)$ & $(0.0202)$ & $(0.0151)$ \\
\hline \multicolumn{5}{|l|}{ s_LF } \\
\hline \multicolumn{5}{|l|}{ s_U } \\
\hline \multirow[t]{2}{*}{ s_Skill } & $1.426^{* * *}$ & $1.365 * * *$ & $1.376^{* * *}$ & $1.403 * * *$ \\
\hline & $(5.46 e-018)$ & $(4.96 e-015)$ & $(2.47 \mathrm{e}-08)$ & $(5.34 \mathrm{e}-09)$ \\
\hline \multirow[t]{2}{*}{ s_IR } & 0.226 & 0.226 & & \\
\hline & $(0.1527)$ & $(0.1403)$ & & \\
\hline \multicolumn{5}{|l|}{ s_SSC } \\
\hline \multicolumn{5}{|l|}{ s_RERvol } \\
\hline \multirow[t]{2}{*}{ s_Openness } & $1.129 * * *$ & $1.072 * * *$ & $0.906 * * *$ & $0.906 * * *$ \\
\hline & $(0.0005)$ & $(0.0014)$ & $(0.0010)$ & $(0.0011)$ \\
\hline \multirow[t]{2}{*}{ s_Road_density } & $1.314 * * *$ & $1.278 * * *$ & $1.435 * * *$ & $1.469 * * *$ \\
\hline & $(1.06 \mathrm{e}-07)$ & $(9.70 \mathrm{e}-07)$ & $(1.79 \mathrm{e}-06)$ & $(1.69 \mathrm{e}-07)$ \\
\hline \multirow[t]{2}{*}{ s_Railway_density } & $0.441 * * *$ & $0.435^{* * *}$ & $0.370 * * *$ & $0.383 * * *$ \\
\hline & $(5.26 \mathrm{e}-05)$ & $(4.62 \mathrm{e}-05)$ & $(0.0001)$ & $(9.98 \mathrm{e}-06)$ \\
\hline \multicolumn{5}{|l|}{ s_Internet } \\
\hline \multirow[t]{2}{*}{ s_Corrup } & $-0.387 * * *$ & $-0.381 * * *$ & $-0.389 * * *$ & $-0.389 * * *$ \\
\hline & $(0.0004)$ & $(0.0006)$ & $(0.0003)$ & $(0.0002)$ \\
\hline \multicolumn{5}{|l|}{ EU } \\
\hline \multirow[t]{2}{*}{ EMU } & $-0.293^{*}$ & $-0.279 * *$ & $-0.341^{*}$ & $-0.266^{* *}$ \\
\hline & $(0.0555)$ & $(0.0295)$ & $(0.0681)$ & $(0.0438)$ \\
\hline \multirow[t]{2}{*}{ Privat } & 0.129 & & & \\
\hline & $(0.4405)$ & & & \\
\hline Adjusted R ${ }^{2}$ & 0.5366 & 0.5469 & 0.5412 & 0.5504 \\
\hline Appropriate model & Pooled OLS & Pooled OLS & Pooled OLS & Pooled OLS \\
\hline
\end{tabular}

Note: $* * *=1 \%$ significance level, $* *=5 \%$ significance level, $*=10 \%$ significance level.

Source: Authors' estimation. 
Annex 5a

The Relation of Yp and Other Determinants to the FDI Inflow into the V4 Countries

\begin{tabular}{|c|c|c|c|c|c|}
\hline & Model 1 & Model 2 & Model 3 & Model 4 & Model 5 \\
\hline \multirow[t]{2}{*}{ s_const } & -0.194 & -0.590 & -0.503 & -0.427 & -0.406 \\
\hline & (0.6983) & $(0.1935)$ & $(0.3487)$ & $(0.1595)$ & (0.1609) \\
\hline \multirow[t]{2}{*}{ s_Yp } & -1.408 & $1.995 * * *$ & $2.064 * * *$ & $2.039 * * *$ & $2.106 * * *$ \\
\hline & $(0.3818)$ & $(3.09 \mathrm{e}-05)$ & $(5.00 \mathrm{e}-08)$ & $(2.51 \mathrm{e}-06)$ & $(2.94 \mathrm{e}-08)$ \\
\hline \multirow[t]{2}{*}{ s_Prod } & $0.514 * * *$ & $0.649 * * *$ & $0.58 * * *$ & $0.584 * * *$ & $0.601 * * *$ \\
\hline & $(0.0027)$ & $(1.60 \mathrm{e}-05)$ & $(4.19 \mathrm{e}-09)$ & $(1.81 \mathrm{e}-09)$ & $(2.57 \mathrm{e}-09)$ \\
\hline \multirow[t]{2}{*}{ s_TAXrate } & -0.273 & $-0.441 * * *$ & $-0.545^{* * *}$ & $-0.542 * * *$ & $-0.576 * * *$ \\
\hline & $(0.1011)$ & $(8.95 e-07)$ & $(0.0050)$ & $(0.0067)$ & $(0.0010)$ \\
\hline \multirow[t]{2}{*}{ s_Capital } & $2.622 * * *$ & & & & \\
\hline & $(5.08 \mathrm{e}-06)$ & & & & \\
\hline \multirow[t]{2}{*}{ s_Wages } & -0.231 & $-0.461 * *$ & $-0.491 * * *$ & $-0.489 * * *$ & $-0.494 * * *$ \\
\hline & $(0.2629)$ & $(0.0272)$ & $(0.0004)$ & $(0.0003)$ & $(0.0002)$ \\
\hline \multirow[t]{2}{*}{ s_ULC } & 0.219 & $0.246^{* * *}$ & $0.258 * * *$ & $0.252 * * *$ & $0.252^{* * *} *$ \\
\hline & $(0.1561)$ & $(0.0060)$ & $(7.69 \mathrm{e}-05)$ & $(9.05 \mathrm{e}-07)$ & $(1.20 \mathrm{e}-06)$ \\
\hline \multirow[t]{2}{*}{ S_Infl } & -0.544 & -0.807 & $-0.403 * * *$ & $-0.415^{* * *}$ & $-0.441^{* * * *}$ \\
\hline & $(0.2952)$ & (0.1676) & $(0.0084)$ & $(0.0014)$ & $(0.0002)$ \\
\hline \multirow[t]{2}{*}{ s_LF } & -0.516 & & & & \\
\hline & $(0.8255)$ & & & & \\
\hline \multirow[t]{2}{*}{ s_U } & $0.914 * *$ & & & & \\
\hline & $(0.0223)$ & & & & \\
\hline \multirow[t]{2}{*}{ s_Skill } & $0.760 * *$ & $1.353 * * *$ & $1.508 * * *$ & $1.484 * * *$ & $1.565 * * *$ \\
\hline & $(0.0105)$ & $(0.0001)$ & $(1.22 \mathrm{e}-06)$ & $(7.98 \mathrm{e}-05)$ & $(2.85 \mathrm{e}-07)$ \\
\hline \multirow[t]{2}{*}{ s_IR } & 0.020 & 0.249 & 0.174 & 0.178 & 0.187 \\
\hline & $(0.9351)$ & $(0.2944)$ & $(0.1424)$ & $(0.1366)$ & $(0.1269)$ \\
\hline \multirow[t]{2}{*}{ s_SSC } & -0.273 & -0.268 & & & \\
\hline & $(0.2781)$ & $(0.3050)$ & & & \\
\hline \multirow[t]{2}{*}{ s_RERvol } & 0.148 & -0.083 & -0.044 & -0.045 & -0.050 \\
\hline & $(0.2826)$ & $(0.2735)$ & $(0.4419)$ & $(0.3997)$ & $(0.3424)$ \\
\hline \multirow[t]{2}{*}{ s_Openness } & $0.670 * * *$ & $0.933 * * *$ & $0.954 * * *$ & $0.926 * * *$ & $0.955^{* * *}$ \\
\hline & $(0.0009)$ & $(0.0034)$ & $(0.0006)$ & $(0.0040)$ & $(0.0015)$ \\
\hline \multirow[t]{2}{*}{ s_Road_density } & $0.956 * * *$ & $1.491 * * *$ & $1.456^{* * *}$ & $1.448 * * *$ & $1.528 * * *$ \\
\hline & $(0.0077)$ & $(7.58 \mathrm{e}-05)$ & $(5.97 \mathrm{e}-05)$ & $(0.0002)$ & $(1.66 \mathrm{e}-06)$ \\
\hline \multirow[t]{2}{*}{ s_Railway_density } & 0.145 & $0.715^{* *}$ & $0.489 * * *$ & $0.494 * * *$ & $0.528 * * *$ \\
\hline & $(0.6862)$ & $(0.0458)$ & $(0.0027)$ & $(0.0015)$ & $(2.74 \mathrm{e}-05)$ \\
\hline \multirow[t]{2}{*}{ s_Internet } & 0.118 & 0.457 & & & \\
\hline & $(0.8712)$ & $(0.5308)$ & & & \\
\hline \multirow[t]{2}{*}{ s_Corrup } & $-0.379 * * *$ & $-0.120 * * *$ & $-0.139 * * *$ & $-0.135 * * *$ & $-0.124 * * *$ \\
\hline & $(1.31 \mathrm{e}-05)$ & $(0.0088)$ & $(0.0042)$ & $(0.0029)$ & $(0.0019)$ \\
\hline \multirow[t]{2}{*}{ EU } & 0.294 & 0.731 & 0.625 & 0.561 & 0.516 \\
\hline & $(0.6154)$ & $(0.1487)$ & $(0.3001)$ & $(0.1738)$ & $(0.1624)$ \\
\hline \multirow[t]{2}{*}{ EMU } & $-0.460 *$ & -0.181 & -0.152 & -0.127 & \\
\hline & $(0.0558)$ & $(0.4048)$ & $(0.5658)$ & $(0.4876)$ & \\
\hline \multirow[t]{2}{*}{ Privat } & 0.053 & 0.154 & 0.121 & & \\
\hline & $(0.8609)$ & $(0.6737)$ & $(0.7614)$ & & \\
\hline Adjusted R² & 0.5554 & 0.5078 & 0.525 & 0.5362 & 0.5468 \\
\hline Appropriate model & Pooled OLS & Pooled OLS & Pooled OLS & Pooled OLS & Pooled OLS \\
\hline
\end{tabular}

Note: $* * *=1 \%$ significance level, $* *=5 \%$ significance level, $*=10 \%$ significance level.

Source: Authors' estimation. 
A n nex 5 b

The Relation of Yp and Other Determinants to the FDI Inflow into the V4 Countries

\begin{tabular}{|c|c|c|c|c|c|}
\hline & Model 6 & Model 7 & Model 8 & Model 9 & Model 10 \\
\hline \multirow[t]{2}{*}{ s_const } & -0.378 & -0.397 & 0.000 & 0.000 & \\
\hline & $(0.2198)$ & $(0.3002)$ & $(1.0000)$ & $(1.0000)$ & \\
\hline \multirow[t]{2}{*}{ s_Yp } & $2.143^{* * *}$ & $2.067 * * *$ & $2.263 * * *$ & $2.220 * * *$ & $2.220 * * *$ \\
\hline & $(1.83 e-08)$ & $(2.16 \mathrm{e}-07)$ & $(4.89 \mathrm{e}-013)$ & $(1.33 \mathrm{e}-010)$ & $(1.13 \mathrm{e}-010)$ \\
\hline \multirow[t]{2}{*}{ s_Prod } & $0.581 * * *$ & $0.586^{* * *}$ & $0.558 * * *$ & $0.543^{* * *} *$ & $0.543^{* * *} *$ \\
\hline & $(1.73 \mathrm{e}-010)$ & $(4.64 \mathrm{e}-010)$ & $(2.06 \mathrm{e}-09)$ & $(4.72 \mathrm{e}-010)$ & $(4.07 \mathrm{e}-010)$ \\
\hline \multirow[t]{2}{*}{ s_TAXrate } & $-0.565 * * *$ & $-0.533 * * *$ & $-0.674 * * *$ & $-0.662 * * *$ & $-0.662 * * *$ \\
\hline & $(0.0014)$ & $(0.0037)$ & $(3.26 \mathrm{e}-09)$ & $(3.48 \mathrm{e}-09)$ & $(3.08 \mathrm{e}-09)$ \\
\hline \multicolumn{6}{|l|}{ s_Capital } \\
\hline \multirow[t]{2}{*}{ s_Wages } & $-0.499 * * *$ & $-0.463 * * *$ & $-0.528 * * *$ & $-0.570 * * *$ & $-0.570 * * *$ \\
\hline & $(4.22 \mathrm{e}-05)$ & $(1.75 e-05)$ & $(5.40 \mathrm{e}-06)$ & $(7.87 \mathrm{e}-06)$ & $(7.51 \mathrm{e}-06)$ \\
\hline \multirow[t]{2}{*}{ s_ULC } & $0.266^{* * * *}$ & $0.305 * * *$ & $0.273 * * *$ & $0.234 * * *$ & $0.234 * * *$ \\
\hline & $(1.55 \mathrm{e}-08)$ & $(6.48 \mathrm{e}-09)$ & $(3.51 \mathrm{e}-018)$ & $(1.42 \mathrm{e}-08)$ & $(1.28 \mathrm{e}-08)$ \\
\hline \multirow[t]{2}{*}{ s_Infl } & $-0.472 * * *$ & $-0.500 * * *$ & $-0.492 * * *$ & $-0.525 * * *$ & $-0.525^{* * *}$ \\
\hline & $(0.0001)$ & $(8.99 \mathrm{e}-05)$ & $(0.0001)$ & $(0.0002)$ & $(0.0002)$ \\
\hline \multicolumn{6}{|l|}{ s_LF } \\
\hline \multicolumn{6}{|l|}{ s_U } \\
\hline \multirow[t]{2}{*}{ s_Skill } & $1.588 * * *$ & $1.600 * * *$ & $1.872 * * *$ & $1.921 * * *$ & $1.921 * * *$ \\
\hline & $(1.02 \mathrm{e}-06)$ & $(7.35 e-05)$ & $(9.51 \mathrm{e}-014)$ & $(1.54 \mathrm{e}-013)$ & $(1.18 \mathrm{e}-013)$ \\
\hline \multirow[t]{2}{*}{ s_IR } & 0.158 & & & & \\
\hline & $(0.2219)$ & & & & \\
\hline \multicolumn{6}{|l|}{ s_SSC } \\
\hline \multicolumn{6}{|l|}{ s_RERvol } \\
\hline \multirow[t]{2}{*}{ s_Openness } & $0.989 * * *$ & $0.891 * * *$ & $1.039 * * *$ & $0.997 * * *$ & $0.997 * * *$ \\
\hline & $(0.0008)$ & $(0.0032)$ & $(5.50 \mathrm{e}-06)$ & $(0.0002)$ & $(0.0002)$ \\
\hline \multirow[t]{2}{*}{ s_Road_density } & $1.578 * * *$ & $1.700 * * *$ & $1.924 * * *$ & $1.960 * * *$ & $1.960 * * *$ \\
\hline & $(4.29 \mathrm{e}-06)$ & $(1.41 \mathrm{e}-05)$ & $(2.03 \mathrm{e}-012)$ & $(3.59 \mathrm{e}-012)$ & $(2.89 \mathrm{e}-012)$ \\
\hline \multirow[t]{2}{*}{ s_Railway_density } & $0.539 * * *$ & $0.499 * * *$ & $0.573 * * *$ & $0.566^{* * *}$ & $0.566^{* * *}$ \\
\hline & $(8.12 \mathrm{e}-06)$ & $(6.21 \mathrm{e}-05)$ & $(6.13 \mathrm{e}-011)$ & $(5.94 \mathrm{e}-08)$ & $(5.42 \mathrm{e}-08)$ \\
\hline \multicolumn{6}{|l|}{ s_Internet } \\
\hline \multirow[t]{2}{*}{ s_Corrup } & $-0.133 * * *$ & $-0.154 * * *$ & -0.112 & & \\
\hline & $(0.0045)$ & $(0.0059)$ & $(0.1492)$ & & \\
\hline \multirow[t]{2}{*}{ EU } & 0.482 & 0.505 & & & \\
\hline & $(0.2215)$ & $(0.3050)$ & & & \\
\hline \multicolumn{6}{|l|}{ EMU } \\
\hline \multicolumn{6}{|l|}{ Privat } \\
\hline Adjusted $\mathrm{R}^{2}$ & 0.5558 & 0.5578 & 0.5612 & 0.5659 & 0.5753 \\
\hline Appropriate model & Pooled OLS & Pooled OLS & Pooled OLS & Pooled OLS & Pooled OLS \\
\hline
\end{tabular}

Note: $* * *=1 \%$ significance level, $* *=5 \%$ significance level, $*=10 \%$ significance level.

Source: Authors' estimation. 
Annex 6

Source of the Data

\begin{tabular}{|c|c|c|}
\hline Variable & Abbreviation & Source \\
\hline $\begin{array}{l}\text { Foreign direct investment inflow } \\
\text { (mil. USD, constant prices 2005) }\end{array}$ & FDI & UNCTADstat \\
\hline $\begin{array}{l}\text { Gross domestic product } \\
\text { (mil. USD, constant prices 2005) }\end{array}$ & GDP & UNCTADstat \\
\hline Economic growth (in \%) & g & UNCTADstat \\
\hline $\begin{array}{l}\text { Potential output } \\
\text { (mil. USD, constant prices 2005) }\end{array}$ & Yp & calculation of authors, OECD \\
\hline Output gap (Yr - Yp, in \%) & YrYp & OECD \\
\hline $\begin{array}{l}\text { Labour productivity } \\
\text { (USD, constant prices 2005) }\end{array}$ & Prod & calculation of authors, OECD \\
\hline Corporate tax (in \%) & TAXrate & OECD \\
\hline $\begin{array}{l}\text { Gross fixed capital formation } \\
\text { (mil. USD, constant prices 2005) }\end{array}$ & Capital & calculation of authors, UNCTADstat \\
\hline $\begin{array}{l}\text { Average annual wage } \\
\text { (USD, constant prices 2005) }\end{array}$ & Wages & calculation of authors, OECD \\
\hline Unit labour cost (annual growth rate in \%) & ULC & OECD \\
\hline Inflation $(\mathrm{CPI}$ index, $2005=100)$ & Infl & UNCTADstat \\
\hline $\begin{array}{l}\text { Labour force } \\
\text { (thousands persons, years } 25-64 \text { ) }\end{array}$ & LF & OECD \\
\hline $\begin{array}{l}\text { Unemployment } \\
\text { (thousands persons, years } 25-64 \text { ) }\end{array}$ & $\mathrm{U}$ & OECD \\
\hline $\begin{array}{l}\text { Qualified labour force } \\
\text { (percentage of persons with secondary } \\
\text { education to total labour force, years } 25-64 \text { ) }\end{array}$ & Skill & OECD \\
\hline Long-term interest rate (in \%) & IR & OECD \\
\hline $\begin{array}{l}\text { Social security contributions of employers } \\
\text { for } 1 \text { employee (USD, constant prices 2005) }\end{array}$ & SSC & calculation of authors, OECD \\
\hline Volatility of Exchange rate (\% change) & RERvol & UNCTADstat \\
\hline $\begin{array}{l}\text { Openness of the economy } \\
\text { (mil. USD, constant prices 2005) }\end{array}$ & Openness & calculation of authors, UNCTADstat \\
\hline Road density $\left(\mathrm{km} / 100 \mathrm{~km}^{2}\right)$ & Road_density & OECD \\
\hline Railway density $\left(\mathrm{km} / 100 \mathrm{~km}^{2}\right)$ & Railway_density & OECD \\
\hline Internet users (per 100 inhabitants) & Internet & World Bank \\
\hline Corruption perceptions index (score) & Corrup & Transparency international \\
\hline $\begin{array}{l}\text { Membership in the European union } \\
(\text { yes }=1, \text { no }=0)\end{array}$ & $\mathrm{EU}$ & Europa.eu \\
\hline $\begin{array}{l}\text { Membership in the European monetary union } \\
(\text { yes }=1, \text { no }=0 \text { ) }\end{array}$ & EMU & Europa.eu \\
\hline $\begin{array}{l}\text { Privatization (high intensity of privatization } \\
=1, \text { low intensity or no privatization }=0 \text { ) }\end{array}$ & Privat & World Bank \\
\hline
\end{tabular}

